\title{
Cloning, expression, and antiviral activity of interferon $\beta$ from the Chinese microbat, Myotis davidii
}

\author{
Ying-Zi Liang ${ }^{1 *}$, Li-Jun Wu ${ }^{1}$, Qian Zhang ${ }^{1}$, Peng Zhou ${ }^{2}$, Mei-Niang Wang ${ }^{1}$, Xing-Lou Yang ${ }^{1}$, Xing-Yi Ge ${ }^{1}$, \\ Lin-Fa Wang ${ }^{2}$, Zheng-Li Shi ${ }^{1 凶}$
}

1. Key Laboratory of Special Pathogens and Biosafety, Wuhan Institute of Virology, Chinese Academy of Sciences, Wuhan 430071, China

2. Program in Emerging Infectious Diseases, Duke-National University of Singapore Graduate Medical

School, Singapore 169857, Singapore

*Present address: Department of Plastic Surgery, Xijing Hospital, Fourth Military Medical University, Xi'an

710032, China

Bats are natural reservoir hosts for many viruses that produce no clinical symptoms in bats. Therefore, bats may have evolved effective mechanisms to control viral replication. However, little information is available on bat immune responses to viral infection. Type I interferon (IFN) plays a key role in controlling viral infections. In this study, we report the cloning, expression, and biological activity of interferon $\beta$ (IFN $\beta$ ) from the Chinese microbat species, Myotis davidii. We demonstrated the upregulation of IFNB and IFN-stimulated genes in a kidney cell line derived from $M$. davidii after treatment with polyl:C or infection with Sendai virus. Furthermore, the recombinant IFN $\beta$ inhibited vesicular stomatitis virus and bat adenovirus replication in cell lines from two bat species, M. davidii and Rhinolophus sinicus. We provide the first in vitro evidence of IFN $\beta$ antiviral activity in microbats, which has important implications for virus interactions with these hosts.

\section{KEYWORDS bat; interferon; IFN-stimulated genes; antiviral activity}

\section{INTRODUCTION}

Novel human pathogens continue to emerge, the majority of which originate in wildlife (Jones et al., 2008). Bats are the only flying mammals. They make up approximately $20 \%$ of extant mammalian diversity, representing the second largest order of mammals after rodents. Bats are found on all continents, except in polar regions and a few oceanic islands. The diversity of bat species and some of their unique biological features have allowed them to serve as natural reservoir hosts for many viruses (Shi, 2013). Some bat species carry emerging or reemerging infectious disease agents, including severe

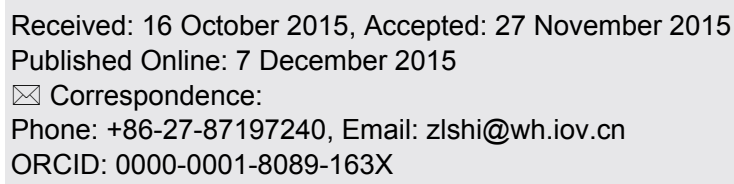

acute respiratory syndrome coronaviruses (Lau et al., 2005; Li et al., 2005; Ge et al., 2013), henipaviruses (Halpin et al., 2000; Chua et al., 2002), and Ebola viruses (Pourrut et al., 2009). These viruses are pathogenic to humans and other mammals, but appear to cause no clinical disease in bats during natural or experimental infection (Williamson et al., 1998; Williamson et al., 2000; Middleton et al., 2007). The long co-evolutionary history of bats and viruses may have resulted in the adaptation of bats' immune systems to cope with viral infection. It is hypothesized that bat innate immunity allows bats to limit viral replication to very low levels, allowing persistent infections of viruses in bat populations (Papenfuss et al., 2012). However, because little information is currently available on any aspect of bat immunology and few bat-specific reagents exist, this hypothesis remains untested.

One of the earliest immune responses initiated after viral infection is the production of interferons (IFNs). 
IFNs provide the first line of defense against viral infection and play a pivotal role in complex cytokine networks (Randall and Goodbourn, 2008). Type I IFNs, some of the most important antiviral immune factors, are associated with the host's ability to reduce viral replication by inducing the expression of IFN-stimulated genes (ISGs).

To understand bat-virus interactions, the Australian black flying fox, Pteropus alecto, has been used as a model bat species (Crameri et al., 2009). This species is the reservoir of a variety of closely related viruses, including rabies virus, Hendra virus, and Nipah virus (Marsh and Wang, 2012). Some genes involved in the immune responses of $P$. alecto have been identified, and functional studies of these genes have been performed (Baker et al., 2010; Cowled et al., 2011; Virtue et al., 2011; Zhou et al., 2011a; Zhou et al., 2011b; Cowled et al., 2012). Type I IFNs were recently described in two other species of fruit bats, the Egyptian rousette, Rousettus aegyptiacus; the Malaysian flying fox, Pteropus vampyrus (Omatsu et al., 2008; Kepler et al., 2010); and two species of microbats, Rhinolophus affinis and Rhinolophus sinicus (Li et al., 2015). In this study, we analyzed the sequence and antiviral activity of IFN $\beta$ cloned from a Chinese microbat species, Myotis davidii. Our results demonstrate that IFN receptor (IFNR) binding site sequences of IFN $\beta$ are conserved and that in vitro antiviral activity is similar across many mammalian genera, including Myotis.

\section{MATERIALS AND METHODS}

\section{Cell lines}

Culture conditions for bat cell lines have been described previously ( $\mathrm{Li}$ et al., 2010). The cell lines used in this study included an M. davidii primary kidney cell line (MdKi, previously called BK) and an immortalized Rhinolophus sinicus kidney cell line (RsKT). The MdKi cells were cultured with RPMI 1640 medium, supplemented with $10 \%$ fetal bovine serum, $100 \mathrm{U} / \mathrm{mL}$ penicillin, and $0.1 \mathrm{mg} / \mathrm{mL}$ streptomycin. The RsKT cells were cultured in DMEM/F12-Hams medium, supplemented with $10 \%$ fetal bovine serum, $100 \mathrm{U} / \mathrm{mL}$ penicillin, and $0.1 \mathrm{mg} / \mathrm{mL}$ streptomycin. All cells were maintained at 37 ${ }^{\circ} \mathrm{C}$ in an incubator supplemented with $5 \% \mathrm{CO}_{2}$.

\section{Viral culture}

Bat adenovirus TJM (BtAdV-TJM) was grown in MdKi cells for $48 \mathrm{~h}$ in a humidified atmosphere of $5 \%$ $\mathrm{CO}_{2}$ at $37{ }^{\circ} \mathrm{C}$ (Li et al., 2010). The virus-containing supernatant was collected and the $50 \%$ tissue culture infective dose $\left(\mathrm{TCID}_{50}\right)$ was determined. Vesicular stomatitis virus-green fluorescent protein (VSV-GFP) (Fernandez, 2002) was grown in $293 \mathrm{~T}$ cells for $48 \mathrm{~h}$, the virus-containing supernatant was collected, and the $\mathrm{TCID}_{50}$ was determined. Sendai virus $(\mathrm{SeV})$ was propagated in 10-day-old embryonated eggs, and the viral titer was determined by hemagglutination assays using chicken red blood cells.

\section{Stimulation of bat cells with poly I:C treatment and SeV infection}

MdKi cells were seeded at $1 \times 10^{6}$ cells/well in 6-well tissue culture plates. The cells were stimulated by transfection with $2 \mu \mathrm{g} / \mathrm{mL}$ polyI:C (InvivoGen) using $5 \mu \mathrm{L}$ of Lipofectamine 2000 (InvivoGen) or by infection with $\mathrm{SeV}$ at 100 hemagglutinating units (HAU)/well. After stimulation, the cells were cultured in a humidified atmosphere of $5 \% \mathrm{CO}_{2}$ at $37{ }^{\circ} \mathrm{C}$. The cells were harvested in RLT buffer (Qiagen) at $0,6,12$, and $18 \mathrm{~h}$ post-infection (hpi) and stored at $-80{ }^{\circ} \mathrm{C}$ until the RNA was extracted.

\section{PCR amplification of the M. davidii IFN $\beta$ gene (IFNB)}

The complete $I F N B$ gene was identified in the $M$. davidii genome (GenBank accession no: XM_006764946). PCR and random amplification of cDNA ends (RACE) primers (Table 1) were designed based on the M. davidii genomic sequence. MdKi cells were infected with $\mathrm{SeV}$ and total RNA was extracted 6 hpi for use as a template for $I F N B$ gene amplification. The samples were homogenized using QIAshredder (Qiagen). Total RNA was extracted using the RNeasy Mini Kit (Qiagen) with oncolumn DNase I treatment (Qiagen) to remove all traces of genomic DNA. The full-length sequence of $I F N B$ was obtained using $5^{\prime}$ and $3^{\prime}$ RACE with the Full RACE Kit (Takara). The DNA amplification conditions included an initial denaturation step at $95^{\circ} \mathrm{C}$ for $5 \mathrm{~min} ; 40$ cycles of denaturation at $94{ }^{\circ} \mathrm{C}$ for $30 \mathrm{~s}$, annealing at $53^{\circ} \mathrm{C}$ for 30 $\mathrm{s}$, and extension at $72^{\circ} \mathrm{C}$ for $50 \mathrm{~s}$; and a final extension at $72{ }^{\circ} \mathrm{C}$ for $10 \mathrm{~min}$.

\section{Sequencing and phylogenetic analysis}

The PCR and RACE products were cloned into the pGEM-T Easy Vector (Promega) for sequencing. The GenBank accession numbers of the sequences used in the phylogenetic analysis are as follows: NP_001092910, Equus caballus (horse); NP_002167, Homo sapiens (human); XP 528553, Pan troglodytes (chimpanzee); NP_034640, Mus musculus (mouse); NP_062000, Rattus norvegicus (rat); NP_001129259, Canis lupus familiaris (dog); AAA31056, Sus scrofa (pig); NP_776775, Bos taurus (cattle); XP_006765009, Myotis davidii; XP_006098187, Myotis lucifugus; ELK06976, P. alecto; BAF37103, Rousettus aegyptiacus; NP_001020007, Gallus gallus (chicken); XP 002708014, Oryctolagus cuniculus (rabbit); KM056305, Rhinolophus sinicus (Chinese rufous horseshoe bat); and KM056306, Rhino- 
lophus affinis (intermediate horseshoe bat). All sequence alignments were performed with the ClustalW program and visualized with GeneDoc software (Thompson et al., 1994). Signal peptides were identified with SignalP version 3.0. Protein domains were identified using the NCBI Conserved Domains search tool (Marchler-Bauer et al., 2011). The phylogenetic tree was generated in MEGA 6 using the neighbor-joining method with 1000 bootstrap replicates.

\section{Expression of bat IFN $\beta$ in Escherichia coli and purification of the protein}

The bat $I F N B$ was cloned into the pET32a expression vector and was used to transform Escherichia coli strain DH10B. The clones were analyzed with restriction digestion to confirm the correct orientation of IFNB. Briefly, Escherichia coli strain BL21 (pET32-IFN $\beta$ ) was cultured, induced with isopropyl- $\beta$-D-thiogalactoside, and then harvested by centrifugation. The sonicated cell lysates were treated with Triton X-100. The proteins were then immobilized on a metal affinity chromatography column and eluted with imidazole. Samples for analysis were collected at each purification step and separated on a $12 \%$ sodium dodecyl sulfate polyacrylamide gel electrophoresis (SDS-PAGE) gel. Western blotting was performed with a His-tag-directed antibody as the primary antibody $(1: 1000)$ and an alkaline-phosphatase-conjugated goat anti-rabbit IgG antibody (1:2000, Sino-American) as the secondary antibody.

Antiviral activity assay of expressed recombinant bat IFN $\beta$ against VSV-GFP infection in bat cells

A VSV-GFP bioassay was performed to determine the antiviral activity of the expressed recombinant bat IFN $\beta$. MdKi cells and RsKT cells were seeded in 96-well plates at a density of $1 \times 10^{4}$ cells/well. After $24 \mathrm{~h}$, the bat cells were left untreated or were treated for $24 \mathrm{~h}$ with five concentrations of bat IFN $\beta$ diluted in medium and then incubated with VSV-GFP at a multiplicity of infection of 1 . After adsorption for $1.5 \mathrm{~h}$ at $37^{\circ} \mathrm{C}$ in a $5 \% \mathrm{CO}_{2}$ incubator, the inoculum was removed and $100 \mu \mathrm{L}$ of medium was added to each well. GFP expression in the cells was visualized by fluorescence microscopy at $18 \mathrm{hpi}$. The number of fluorescent points was counted to evaluate the inhibitory effect of bat IFN $\beta$.

\section{Antiviral activity assay of bat IFN $\beta$ against bat adenovirus in bat cells}

Similar assays were performed in MdKi and RsKT cells using the bat adenovirus, BtAdV. The two bat cell lines were inoculated with BtAdV at a multiplicity of infection of 1 and incubated for $1 \mathrm{~h}$ at $37^{\circ} \mathrm{C}$. The viruscontaining medium was then replaced with culture medium, and the cultures were incubated for $24 \mathrm{~h}$ in a humidified atmosphere of $5 \% \mathrm{CO}_{2}$ at $37{ }^{\circ} \mathrm{C}$. The culture super- natant was collected and the $\mathrm{TCID}_{50}$ was determined by observation of the cytopathic effect.

\section{Quantitative Real-time PCR}

Quantitative Real-time PCR (qRT-PCR) was performed on the total RNA extracted from the cells. In brief, total RNA was used for the synthesis of cDNA with the PrimeScript ${ }^{\circledR}$ RT Reagent Kit with gDNA Eraser and SYBR ${ }^{\circledR}$ Premix Ex Taq ${ }^{\mathrm{TM}}$ II for real-time PCR (Takara). The relative gene expression after treatment was quantified with the StepOnePlus ${ }^{\mathrm{TM}}$ Real-Time PCR System (Applied Biosystems), and the comparative threshold cycle $(\mathrm{Ct})$ method was used to calculate the fold change in gene expression. Relative gene expression was calculated using the mean values obtained from the arithmetic formula $2^{-\Delta \Delta \mathrm{Ct}}$ (Applied Biosystems). The cycling profile consisted of an initial denaturation at 95 ${ }^{\circ} \mathrm{C}$ for $30 \mathrm{~s}$, and 40 cycles of $95^{\circ} \mathrm{C}$ for $5 \mathrm{~s}$ and $60^{\circ} \mathrm{C}$ for $30 \mathrm{~s}$, followed by a melting curve analysis. All data were normalized to the housekeeping gene for glyceraldehyde3-phosphate dehydrogenase (GAPDH).

\section{RESULTS}

\section{Characterization of $M$. davidii IFN $\beta$}

The expected DNA fragment of $561 \mathrm{bp}$ was amplified from bat cells and sequenced. The deduced protein encoded by IFNB contained many features that are conserved in the IFN $\beta$ proteins of other species, including a signal-peptide cleavage site and several residues that are responsible for the binding of IFN $\beta$ to the type I IFNR (IFNAR) (Figure 1A).

Three-dimensional modeling of the bat IFN $\beta$ structure revealed five putative a-helices (A-E) (Arnold et al., 2006). The $M$. davidii IFN $\beta$ sequence shares $43 \%-85 \%$ amino acid identity with IFN $\beta$ proteins of other mammalian species, sharing the highest similarity with IFN $\beta$ of another Myotis species. A phylogenetic analysis of bat IFN $\beta$ and other IFN $\beta$ sequences from a variety of vertebrates was performed. As previously described (Zhang et al., 2013), $M$. davidii IFN $\beta$ clustered with $M$. lucifugus IFN $\beta$ within the laurasiatherian mammalian sequences (Figure 1B).

\section{Bat IFNs and ISGs were highly upregulated in bat cells after poly I:C treatment and SeV infection}

To examine the expression patterns of bat IFNs in response to polyI: $\mathrm{C}$ treatment or viral challenge, we used polyI:C and $\mathrm{SeV}$ to stimulate MdKi cells. The total RNA in the cells was isolated at different time points after infection. Successful infection by $\mathrm{SeV}$ was confirmed by RT-PCR (data not shown). The expression kinetics of $I F N B$ and ISGs were determined by qRT-PCR. Following $\mathrm{SeV}$ infection, expressions of IFNB and ISGs were 
A
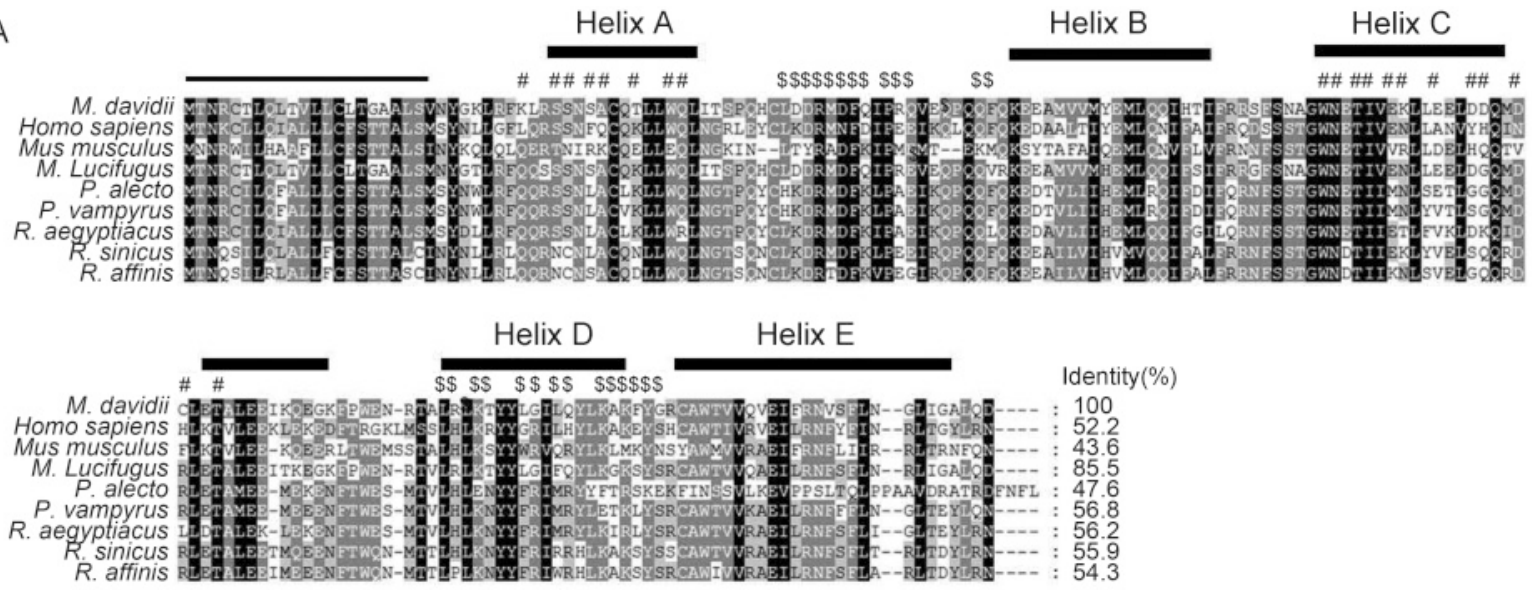

B

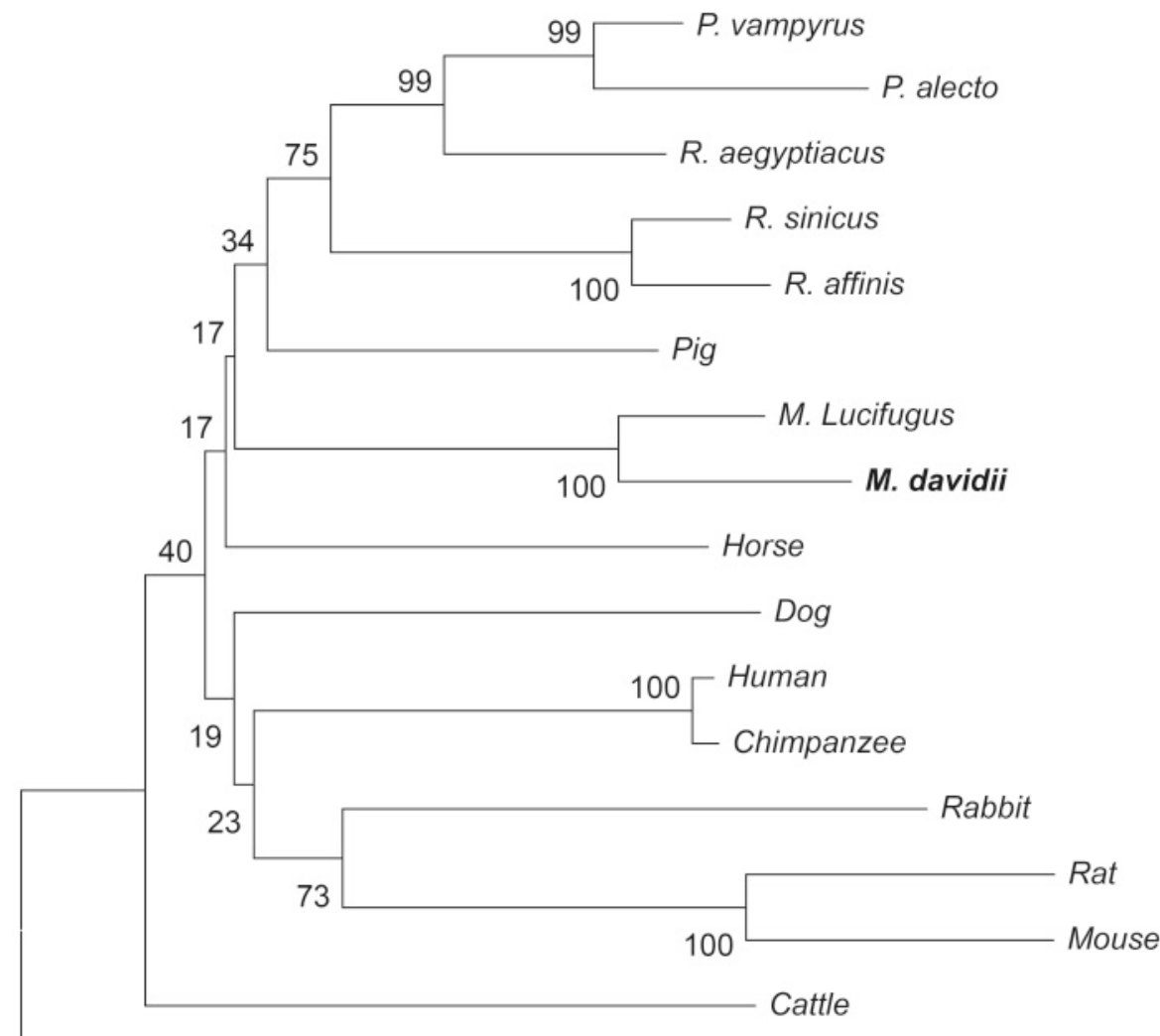

Chicken

0.1

Figure 1. Sequence analysis of Myotis davidii IFNß. (A) ClustalW-generated multiple amino acid sequence alignment of M. davidii and other bats, mice, and humans IFN $\beta$. The predicted signal peptides are underlined. The putative IFNAR1binding sites and IFNAR2-binding sites are indicated with "\#" and " $\$$ ", respectively. The secondary structure of IFN $\beta$ is shown above the alignment. Five helices, designated Helix A-E, are indicated with boxes. (B) Phylogenetic analysis based on an amino acid alignment of bat IFN $\beta$ with those of representative vertebrate species. Percentage branch support calculated with 1000 bootstrap replicates is indicated when it exceeds $60 \%$. M. davidii IFN $\beta$ is highlighted in bold. The accession numbers of the IFN $\beta$ protein sequences used in this analysis are listed in the Materials and Methods. 

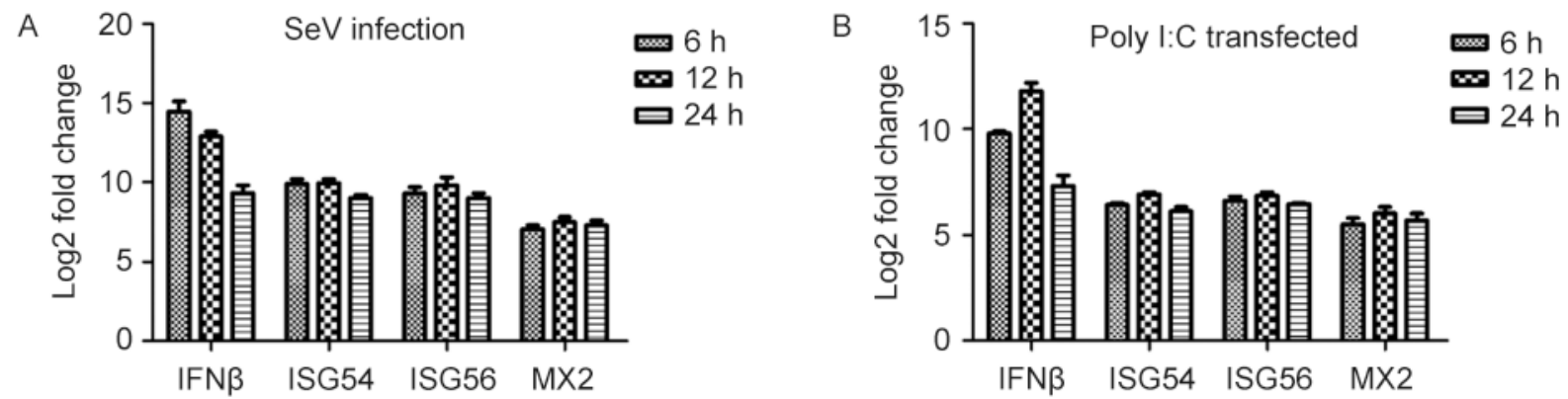

Figure 2. Analysis of bat IFNB and ISG expression in MdKi cells after treatment with polyl:C (A) or infection with SeV (B). Cells were transfected with polyl:C or infected with $\mathrm{SeV}$ and collected at the indicated time points. IFNB and ISG mRNAs were measured by qRT-PCR. The data were normalized to the housekeeping gene GAPDH. Data are the mean values of three separate experiments and the error bars represent standard errors.
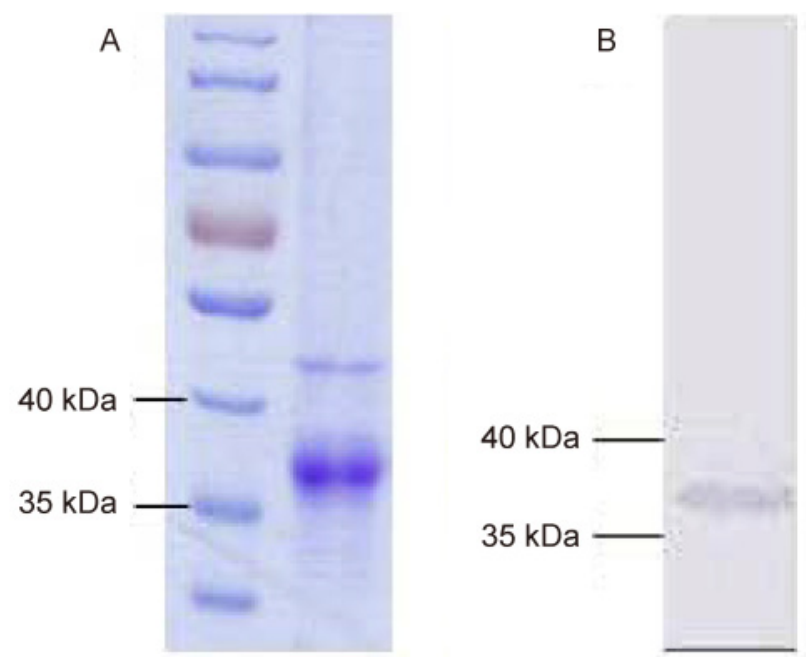

Figure 3. SDS-PAGE (A) and western blotting (B) analyses of recombinant $M$. davidii IFN $\beta$ expressed in Escherichia coli. (A) Purified recombinant $M$. davidii IFN $\beta$ protein was resolved with $12 \%$ SDS-PAGE and analyzed following Coomassie Brilliant Blue staining. (B) Purified recombinant $M$. davidii IFN $\beta$ was analyzed by western blotting, using an antiboday directed against the His tag.

induced at 6 hpi and peaked at $12 \mathrm{hpi}$ (Figure 2A). Similar to $\mathrm{SeV}$ infection, treatment with the double-stranded RNA analog polyI:C also induced IFNB and ISG expression (Figure 2B).

\section{Expressed recombinant bat IFN $\beta$ inhibited virus replication in bat cells}

The expressed recombinant IFN $\beta$ of the Myotis bat was analyzed with SDS-PAGE and confirmed with western blotting using an antibody directed against the His tag (Figure 3). To assess the antiviral activity of the recombinant bat IFN $\beta$, MdKi and RsKT cells were pretreated with bat IFN $\beta$. As shown in Figure 4, the treatment of MdKi and RsKT cells with IFN $\beta$ before VSV-GFP infection caused a significant dose-dependent reduction in the number of VSV-GFP-positive cells compared to those in the mock-treated cells. A similar inhibitory effect was observed during the infection of these two bat cell lines with BtAdV (Figure 5). These results demonstrate that recombinant bat IFN $\beta$ mitigated viral infection in bat cells in vitro.

\section{DISCUSSION}

In this study, we cloned and characterized IFN $\beta$ from a Chinese microbat, $M$. davidii. Compared with IFN $\beta$ sequences from other mammals, the $M$. davidii IFN $\beta$ sequence shares highest amino acid identity with that of $M$. lucifugus (85\%). A number of conserved features were identified in the bat IFN $\beta$ sequence, which is consistent with its functional equivalence to the IFN $\beta$ proteins of other species. To examine the expression pattern of bat IFN $\beta$ in response to polyI:C treatment or viral challenge, we used polyI: $\mathrm{C}$ and $\mathrm{SeV}$ to stimulate MdKi cells. The qRT-PCR results demonstrated that bat IFNB and ISGs 

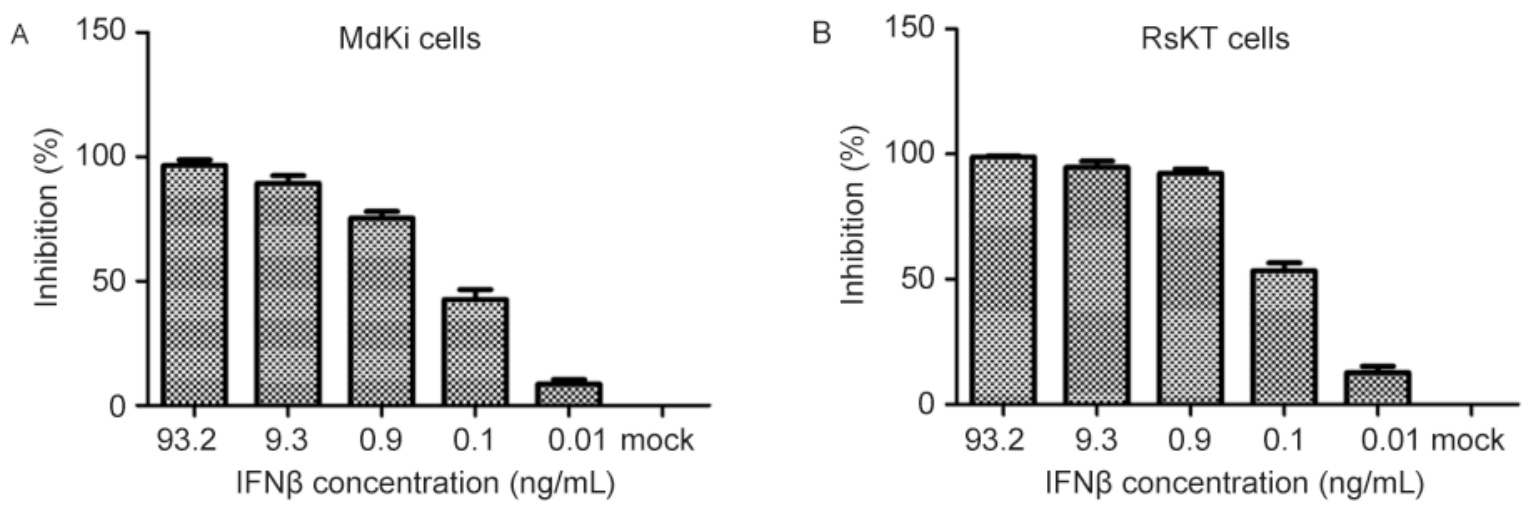

Figure 4. Antiviral activity assay of IFN $\beta$ against VSV-GFP in RsKT cells (A) and MdKi cells (B). Cells were treated for $24 \mathrm{~h}$ with five serial dilutions of IFN $\beta$ in medium and incubated with VSV-GFP. GFP expression in the cells was visualized and measured at $18 \mathrm{hpi}$.

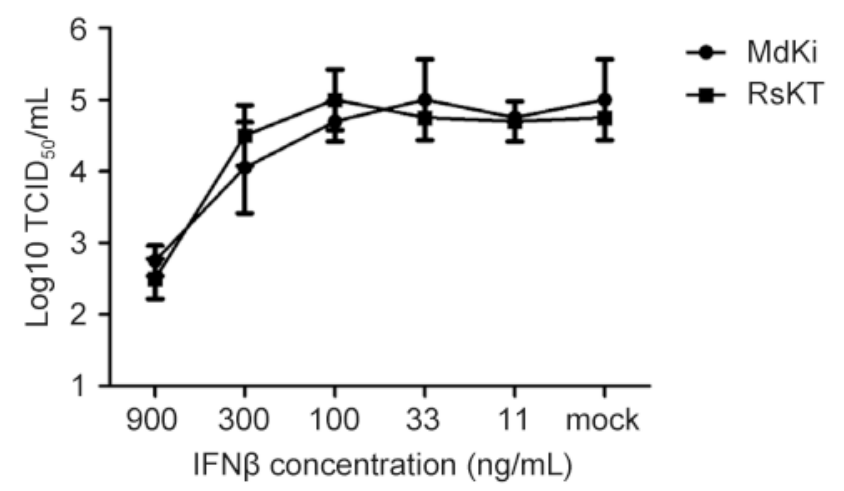

Figure 5. Antiviral activity assay of bat IFN $\beta$ against bat adenovirus (BtAdV) in MdKi and RsKT cells. Cells were treated with serial dilutions of IFN $\beta$ or mock medium for $24 \mathrm{~h}$ and infected with BtAdV for another $24 \mathrm{~h}$. The culture supernatant was collected and the $\operatorname{TCID}_{50}$ was determined by observation of the cytopathic effect.

were highly upregulated in the bat cells after polyI:C treatment or $\mathrm{SeV}$ infection. Furthermore, the expressed recombinant bat IFN $\beta$ protein exerted antiviral activity against human VSV and BtAdV. To our knowledge, this is the first study to report the antiviral activity of IFN $\beta$ in a microbat.

Previous studies have reported that recombinant type III IFN and type II IFN from the megabat $P$. alecto inhibited the replication of Pulau virus, Semliki Forest virus, and Hendra virus (Zhou et al., 2011a; Janardhana et al., 2012). Another research group characterized IFNא and IFN $\omega$ from the European serotine bat, Eptesicus serotinus. Both type I IFNs have been shown to inhibit the replication of different lyssaviruses, to different extents, in susceptible bat cells (He et al., 2014). However, the antiviral activity of microbat IFN $\beta$ is less studied. Here, our results indicate that the $M$. davidii IFN $\beta$ protein has antiviral activity, consistent with type I IFNs of other bat species. Our results also indicate that bat IFN has antiviral activity similar to that of other mammalian IFNs.
As in other mammals, the bat immune system comprises both innate and adaptive elements (Baker et al., 2013; Brook and Dobson, 2015). Recent studies have demonstrated that type I IFN $\alpha$ and IFN $\beta$ from Rousettus aegyptiacus and type II IFN $\gamma$ and type III IFN $\lambda$ from $P$. alecto play crucial roles in virus interactions with these hosts (Zhou et al., 2011b; Janardhana et al., 2012). In addition to IFN sequence characterization, the induction of IFNs, their signaling pathways, and their antiviral activities following viral infection have also been investigated in cell lines derived from Eidolon helvum and P. alecto (Biesold et al., 2011; Virtue et al., 2011). These results provide evidence that the signaling molecules downstream of the IFN response in bats are probably similar to those in other mammals. In addition to the innate immune response, studies have examined the adaptive immune response in bats, demonstrating that bats do mount antibody responses to various viral infections, including lyssaviruses, filoviruses, and henipaviruses (Hayman et al., 2013). However, it seems that their humoral adaptive immunity is less effective at controlling viral trans- 
mission (Plowright et al., 2008; Turmelle et al., 2010; Brook, 2015). From the limited number of bat immune studies available, it seems that the bat has immunological features similar to those of other mammals.

Recently, the whole-genome sequences of two distantly related species, the fruit bat $P$. alecto and the insectivorous bat $M$. davidii, became available (Zhang et al., 2013). Comparative analyses indicated unexpected concentrations of positively selected genes in the DNA damage checkpoint and nuclear factor $\kappa \mathrm{B}$ pathways, which might play a role in bat immunity. Because the DNA damage response plays an important role in host defenses and is a known target of virus interaction, a link between the metabolism and immunity of bats may explain the tolerance to viruses observed in bats (Wang et al., 2011; O'Shea et al., 2014). These issues warrant further investigation to determine whether these unique characteristics are associated with the asymptomatic nature of viral infections in bats.

\section{ACKNOWLEDGMENTS}

This work was funded by the National Natural Science Foundation of China (No. 31321001).

\section{COMPLIANCE WITH ETHICS GUIDELINES}

All experiments were conducted under the guidelines of the Animal Ethics Committee in Wuhan Institute of Virology, Chinese Academy of Sciences. All the authors declare that they have no competing interest.

\section{AUTHOR CONTRIBUTIONS}

Y.L. and Z.S. conceived and designed the experiments; Y.L., L.W., and P.Z. performed the experiments; Y.L., L.W., Q.Z., and M.W. analyzed the data; X.Y. and X.G. provided the reagents and materials essential for the research; Y.L. wrote the paper.

\section{REFERENCES}

Arnold K, Bordoli L, Kopp J, Schwede T. 2006. The SWISSMODEL workspace: a web-based environment for protein structure homology modelling. Bioinformatics, 22: 195-201.

Baker ML, Schountz T, Wang LF. 2013. Antiviral immune responses of bats: a review. Zoonoses Public Health, 60: 104-116.

Baker ML, Tachedjian M, Wang LF. 2010. Immunoglobulin heavy chain diversity in Pteropid bats: evidence for a diverse and highly specific antigen binding repertoire. Immunogenetics, 62: 173-184.

Biesold SE, Ritz D, Gloza-Rausch F, Wollny R, Drexler JF, Corman VM, Kalko EKV, Oppong S, Drosten C, Mueller MA. 2011. Type I interferon reaction to viral infection in interferoncompetent, immortalized cell lines from the African fruit bat Eidolon helvum. PloS One, 6: e28131.
Brook EC, Dobson A. 2015. Bats as 'special' reservoirs for emerging zoonotic pathogens. Trends Microbiol, 23: 172-180.

Chua KB, Koh CL, Hooi PS, Wee KF, Khong JH, Chua BH, Chan YP, Lim ME, Lam SK. 2002. Isolation of Nipah virus from Malaysian Island flying-foxes. Microbes Infect, 4: 145-151.

Cowled C, Baker M, Tachedjian M, Zhou P, Bulach D, Wang LF. 2011. Molecular characterisation of Toll-like receptors in the black flying fox Pteropus alecto. Dev Comp Immunol, 35: 7-18.

Cowled C, Baker ML, Zhou P, Tachedjian M, Wang LF. 2012. Molecular characterisation of RIG-I-like helicases in the black flying fox, Pteropus alecto. Dev Comp Immunol, 36: 657-664.

Crameri G, Todd S, Grimley S, McEachern JA, Marsh GA, Smith C, Tachedjian M, De Jong C, Virtue ER, Yu M, Bulach D, Liu JP, Michalski WP, Middleton D, Field HE, Wang LF. 2009. Establishment, immortalisation and characterisation of pteropid bat cell lines. PLoS One, 4: e8266.

Fernandez M, Porosnicu M, Markovic D, Barber GN. 2002. Genetically engineered vesicular stomatitis virus in gene therapy: application for treatment of malignant disease. J Virol., 76 895-904.

Ge XY, Li JL, Yang XL, Chmura AA, Zhu G, Epstein JH, Mazet JK, Hu B, Zhang W, Peng C, Zhang YJ, Luo CM, Tan B, Wang N, Zhu Y, Crameri G, Zhang SY, Wang LF, Daszak P, Shi ZL. 2013. Isolation and characterization of a bat SARS-like coronavirus that uses the ACE2 receptor. Nature., 28: 535-538.

Halpin K, Young PL, Field HE, Mackenzie JS. 2000. Isolation of Hendra virus from pteropid bats: a natural reservoir of Hendra virus. J Gen Virol, 81: 1927-1932.

Hayman DT, Bowen RA, Cryan PM, McCracken GF, O'Shea TJ, Peel AJ, Gilbert A, Webb CT, Wood JLN. 2013. Ecology of Zoonotic Infectious Diseases in Bats: Current Knowledge and Future Directions. Zoonoses and Public Health, 60: 2-21.

He X, Korytař T, Schatz J, Freuling CM, Müller T, Köllner B. 2014. Anti-lyssaviral activity of interferons $\kappa$ and $\omega$ from the serotine bat, Eptesicus serotinus. J Virol., 88: 5444-5454.

Janardhana V, Tachedjian M, Crameri G, Cowled C, Wang LF, Baker ML. 2012. Cloning, expression and antiviral activity of IFNgamma from the Australian fruit bat, Pteropus alecto. Dev Comp Immunol, 36: 610-618.

Jones KE, Patel NG, Levy MA, Storeygard A, Balk D, Gittleman JL, Daszak P. 2008. Global trends in emerging infectious diseases. Nature, 451: 990-993.

Kepler TB, Sample C, Hudak K, Roach J, Haines A, Walsh A, Ramsburg EA. 2010. Chiropteran types I and II interferon genes inferred from genome sequencing traces by a statistical genefamily assembler. BMC Genomics, 11: 444.

Lau SK, Woo PC, Li KS, Huang Y, Tsoi HW, Wong BH, Wong SS, Leung SY, Chan KH, Yuen KY. 2005. Severe acute respiratory syndrome coronavirus-like virus in Chinese horseshoe bats. Proc Natl Acad Sci U S A, 102: 14040-14045.

Li J, Zhang G, Cheng D, Ren H, Qian M, Du B. 2015. Molecular characterization of RIG-I, STAT-1 and IFN-beta in the horseshoe bat. Gene, 561: 115-123.

Li W, Shi Z, Yu M, Ren W, Smith C, Epstein JH, Wang H, Crameri G, Hu Z, Zhang H, Zhang J, McEachern J, Field H, Daszak P, Eaton BT, Zhang S, Wang LF. 2005. Bats are natural reservoirs of SARS-like coronaviruses. Science, 310: 676-679.

Li Y, Ge X, Zhang H, Zhou P, Zhu Y, Zhang Y, Yuan J, Wang LF, Shi Z. 2010. Host range, prevalence, and genetic diversity of adenoviruses in bats. J Virol, 84: 3889-3897.

Marchler-Bauer A, Lu S, Anderson JB, Chitsaz F, Derbyshire MK, DeWeese-Scott C, Fong JH, Geer LY, Geer RC, Gonzales NR, Gwadz M, Hurwitz DI, Jackson JD, Ke Z, Lanczycki CJ, Lu F, Marchler GH, Mullokandov M, Omelchenko MV, Robertson CL, Song JS, Thanki N, Yamashita RA, Zhang D, Zhang N, Zheng C, Bryant SH. 2011. CDD: a Conserved Domain Database for the functional annotation of proteins. Nucleic Acids 
Res, 39: D225-229.

Marsh GA, Wang LF. 2012. Hendra and Nipah viruses: why are they so deadly? Curr Opin Virol, 2: 242-247.

Middleton DJ, Morrissy CJ, van der Heide BM, Russell GM, Braun MA, Westbury HA, Halpin K, Daniels PW. 2007. Experimental Nipah virus infection in pteropid bats (Pteropus poliocephalus). J Comp Pathol, 136: 266-272.

O'Shea TJ, Cryan PM, Cunningham AA, Fooks AR, Hayman DT, Luis AD, Peel AJ, Plowright RK, Wood JL. 2014. Bat flight and zoonotic viruses. Emerg Infect Dis, 20: 741-745.

Omatsu T, Bak EJ, Ishii Y, Kyuwa S, Tohya Y, Akashi H, Yoshikawa Y. 2008. Induction and sequencing of Rousette bat interferon alpha and beta genes. Vet Immunol Immunopathol, 124: $169-176$.

Papenfuss AT, Baker ML, Feng ZP, Tachedjian M, Crameri G, Cowled C, Ng J, Janardhana V, Field HE, Wang LF. 2012. The immune gene repertoire of an important viral reservoir, the Australian black flying fox. BMC Genomics, 13: 261.

Plowright RK, Field HE, Smith C, Divljan A, Palmer C, Tabor G, Daszak P, Foley JE. 2008. Reproduction and nutritional stress are risk factors for Hendra virus infection in little red flying foxes (Pteropus scapulatus). Proceedings of the Royal Society B-Biological Sciences, 275: 861-869.

Pourrut X, Souris M, Towner JS, Rollin PE, Nichol ST, Gonzalez JP, Leroy E. 2009. Large serological survey showing cocirculation of Ebola and Marburg viruses in Gabonese bat populations, and a high seroprevalence of both viruses in Rousettus aegyptiacus. BMC Infect Dis, 9: 159.

Randall RE, Goodbourn S. 2008. Interferons and viruses: an interplay between induction, signalling, antiviral responses and virus countermeasures. J Gen Virol, 89: 1-47.

Shi Z. 2013. Emerging infectious diseases associated with bat viruses. Sci China Life Sci, 56: 678-682.

Thompson JD, Higgins DG, Gibson TJ. 1994. CLUSTAL W: improving the sensitivity of progressive multiple sequence alignment through sequence weighting, position-specific gap penal- ties and weight matrix choice. Nucleic Acids Res, 22: 4673-4680.

Turmelle AS, Jackson FR, Green D, McCracken GF, Rupprecht CE. 2010. Host immunity to repeated rabies virus infection in big brown bats. J Gen Virol, 91: 2360-2366.

Virtue ER, Marsh GA, Baker ML, Wang LF. 2011. Interferon production and signaling pathways are antagonized during henipavirus infection of fruit bat cell lines. PLoS One, 6: e22488.

Wang LF, Walker PJ, Poon LL. 2011. Mass extinctions, biodiversity and mitochondrial function: are bats 'special' as reservoirs for emerging viruses? Curr Opin Virol, 1: 649-657.

Williamson MM, Hooper PT, Selleck PW, Gleeson LJ, Daniels PW, Westbury HA, Murray PK. 1998. Transmission studies of Hendra virus (equine morbillivirus) in fruit bats, horses and cats. Aust Vet J, 76: 813-818.

Williamson MM, Hooper PT, Selleck PW, Westbury HA, Slocombe RF. 2000. Experimental hendra virus infectionin pregnant guinea-pigs and fruit Bats (Pteropus poliocephalus). J Comp Pathol, 122: 201-207.

Zhang G, Cowled C, Shi Z, Huang Z, Bishop-Lilly KA, Fang X, Wynne JW, Xiong Z, Baker ML, Zhao W, Tachedjian M, Zhu Y, Zhou P, Jiang X, Ng J, Yang L, Wu L, Xiao J, Feng Y, Chen Y, Sun X, Zhang Y, Marsh GA, Crameri G, Broder CC, Frey KG, Wang LF, Wang J. 2013. Comparative analysis of bat genomes provides insight into the evolution of flight and immunity. Science, 339: 456-460.

Zhou P, Cowled C, Marsh GA, Shi Z, Wang LF, Baker ML. 2011a. Type III IFN receptor expression and functional characterisation in the pteropid bat, Pteropus alecto. PLoS One, 6: e25385.

Zhou P, Cowled C, Todd S, Crameri G, Virtue ER, Marsh GA, Klein R, Shi Z, Wang LF, Baker ML. 2011b. Type III IFNs in pteropid bats: differential expression patterns provide evidence for distinct roles in antiviral immunity. J Immunol, 186: 3138-3147. 